\title{
EXPRESSION OF GALECTIN 9 mRNA IN LACTOSE MALDIGESTION AND CHILDREN'S OBESITY
}

\author{
Abaturov $A E^{1}$, Nikulina $A A^{2 *}$
}

Author information: ${ }^{1}$ Department of Pediatrics 1 and Medical Genetics, State Institution Dnepropetrovsk Medical Academy of the Ministry of Health of Ukraine, e-mail: alexandrabaturov56@gmail.com.

$2^{2 *}$ Department of Pediatrics 1, Department of Pediatrics 1 and Medical Genetics, State Institution Dnepropetrovsk Medical Academy of the Ministry of Health of Ukraine, e-mail: anna.nikulina.201381@gmail.com

\begin{abstract}
Introduction: To investigate the association of mRNA expression of galectin-9 (Gal-9) and lactose maldigestion in obese children with different genotypes [13910 C>T polymorphism (rs4988235) of MCM6 (minichromosome maintenance complex 6].

Methods: The study involved 85 obese children (BMI>97 percentile) aged 6-18 years. The definition of MCM6 polymorphism (material for investigation-venous blood) and expression of Gal-9 mRNA (material for investigation-buccal epithelium) were determined by real-time polymerase chain reaction analysis using actin as a housekeeping gene $\triangle \mathrm{mRNA}-\mathrm{Gal}-9 / \mathrm{mRNA}$ actin, relation units-RU. Lactose maldigestion was studied using hydrogen breath testing. The first group of observations included 44 children with genotype $C / C_{-13910}$, the second group consisted of 41 children with phenotypically identical genotypes $C / T$ -13910, and T/T $-13910, p>0.05$.

Results: Lactose maldigestion in children with genotype $\mathrm{C} / \mathrm{C}_{-13910}$ averaged $36.05 \pm 4.73 \mathrm{ppm}$, in children with genotype $C / T-1391022.61 \pm 4.1 \mathrm{ppm}(p<0.05)$, and with genotype $\mathrm{T} / \mathrm{T}-13910$ was absent $(p<0.05)$. The average expression level of Gal-9 mRNA in children with genotype $C / C{ }_{-13910}$ was $564.6 \pm 35.8$, in children with genotypes $\mathrm{C} / \mathrm{T}$ and $\mathrm{T} / \mathrm{T}-1391061.02 \pm 15.8 \mathrm{RU}, p<0.01$. The lowest mean level of expression of Gal-9 mRNA (42.47 \pm 13.4$)$ was recorded in the subgroup of children with genotype C/C -13910 and lactose maldigestion $(n=22)$. Whereas the largest mean level of expression of Gal-9 mRNA was recorded in the subgroup of children with the $C / C_{-13910}$ genotype and without lactose maldigestion $(n=22) 1086.73 \pm 51.2$, $p<0.01$.

Conclusions: The expression level of Gal-9 mRNA depends on lactose maldigestion in children with genotype $\mathrm{C} / \mathrm{C}_{-13910 \text {. }}$
\end{abstract}

Key words: galectin-9, obesity, children, maldigestion of lactose, lactase

INTRODUCTION Lactase deficiency (LD) (hypolactasia) can be congenital or acquired or lactase can be completely absent (alactasia). The lactase enzyme (lactase-phlorizin hydrolase, LCT, LPH, E.C.3.2.1.108) is expressed by differentiated enterocytes of the small intestine and is retained by glycocalyx in the apical part of the ciliated villus epithelium.

The two intronic variations in the MCM6 (minichromosome maintenance complex component 6) gene that are found to be associated with lactase persistence/non-persistence are located approximately 14

\footnotetext{
*Corresponding author Nikulina AA,

9, Vernadsky St.,Dnipro, 49044, Ukraine;

e-mail: anna.nikulina.201381@gmail.com
}

Abaturov $A E$, Nikulina $A A^{\circledR}$ $\mathrm{kb}$ and $22 \mathrm{~kb}$ upstream of the lactase gene ( $L C T$, MIM 603202, rs 4988235, chromosome 2q21) [1].

Single nucleotide polymorphisms (SNPs), due to the formation of specific alleles of genes, make an important contribution to phenotypic differences between people, including personality characteristics in the development of protective reactions, as well as predisposition to a number of diseases [2]. Human LCT gene polymorphisms are associated with the development of congenital lactase deficiency [3], and the SNP intronic regions of MCM6 are associated with lactase persistence [4]. The "wild" variant of the intronic regions sequence is associated with a gradual age-related suppression of the LCT gene expression and the development of primary adult-type hypolactasia, but the replacement of one nucleotide in certain places of the MCM6 enhancer region is accompanied by high expression of the LCT gene 
throughout life. This phenomenon is demonstrated by in vitro experiments showing the strong binding of the transcription factor octamer-binding protein 1 (Oct-1) to the $T_{-13910}$ variant, which can enhance the activity of the LCT gene promoter and increase the expression levels of LPH mRNA in the intestinal mucosa [5]. Given that the allele with MCM6 enhancer polymorphisms is dominant, both homo- and heterozygous individuals are characterized by lactase persistence. There are three genotypic variants of the SNP enhancer MCM6. The C/C 13910 genotype is associated with a decrease in lactase production. Genotype $\mathrm{C} / \mathrm{T}_{-13910}$ is associated with moderate retention of lactase production, and genotype $T / T_{-13910}$ is associated with long-term retention of lactase production [1].

Galectin-9 (Gal-9) is a specific ligand for the phagocytic receptor of cellular apoptosis Tim-3 (T-cell immunoglobulin and the mucin 3 domain), a regulator of glucose and urate transport, and an acidophilic granulocyte chemoattractant [6-8]. Tim-3 receptor, after binding to Gal-9, induces apoptosis of Th ${ }_{1}$ cells [9]. Excess lactose, by binding to Gal-9, prevents the activation of Tim3 , and plays a crucial role as an inhibitor of the activity of $\mathrm{CD}^{+} \mathrm{CD} 25^{+} \mathrm{CD} 127^{-} \mathrm{T}_{\text {reg }}$-mediated suppression of immune $\mathrm{Th}_{1}-\mathrm{Th}_{17}$ responses [10]. Apoptosis of $\mathrm{Th}_{1}$ cells leads to a decrease in the production of pro-inflammatory cytokines such as IFN- $\gamma$, IL-2, IL-3, IL-12, TNF- $\alpha$, TNF- $\beta$, and lymphotoxin, and provides an anti-inflammatory effect. Apoptosis of $\mathrm{Th}_{17}$ cells causes a decrease in the production of IL-6, IL-17A, IL-17F, IL-21, IL-22, IL-23, and TNF- $\beta$, causing inhibition of autoimmune reactions [11]. Thus, the Gal-9 protein is a key molecular regulator of the activity of the immune system, which produces its action by inducing apoptosis of $\mathrm{Th}_{1}$ and $\mathrm{Th}_{17}$ cells due to excitation of the calcium-calpain-caspase- 1 cascade $[10,12]$. Recent studies have provided evidence that the Gal-9/Tim-3 signaling pathway may be an important pathogenetic mechanism for the development of obesity, insulin resistance, and type 2 diabetes mellitus [13-15]. The combination of excessive intake of lactose with food with a simultaneous age-related decrease in the activity of lactase increases the likelihood of immune-mediated human diseases, including obesity, the so-called disease of civilization.

We investigated the association of mRNA expression of Gal-9 and lactose maldigestion in obese children with different variations in the intronic regions of MCM6 that have influence on $L C T$.
MATERIAL AND METHODS The study involved 85 obese children ( 54 boys and 31 girls with $\mathrm{BMI}>97$ percentile) aged 6-18 years.

\section{Genotyping of the MCM6 enhancer of the LCT gene}

The study was conducted in the certified laboratory of Synevo-Ukraine. Genotyping for signs of allelic polymorphism of the MCM6: C-13910T of the LCT gene was begun with the extraction of genomic DNA from peripheral blood leukocytes using the AmliPrime DNASorb B reagent kit (No FSP 2012/4019) according to the manufacturer's instructions (NextBio, Moscow, Russian Federation). Genotypes of the MCM6 enhancer of the $L C T$ gene were detected using $\operatorname{TaqMan}^{\circledR}$ probes for polymerase chain reaction with real-time detection of the results (RT-PCR) on a CFX 96 amplifier (BioRad, Hercules, CA, USA). The technology includes the following steps: 1) amplification of the desired DNA sequence; 2) hybridization of amplicons with oligonucleotides labeled with fluorophores; 3) the formation of complementary and partially complementary duplexes; 4) melting (denaturation) of duplexes; and 5) detection of fluorescence with the subsequent construction and analysis of melting curves $[16,17]$. The PCR amplification was performed with the addition of up to $0.75 \mu \mathrm{l}(20 \mathrm{ng})$ of isolated DNA, $20 \mu \mathrm{g}$ of SNP Genotyping Assay Mix (Applied Biosystems, Foster City, CA, USA), and 2 ng of Universal PCR Master Mix buffer solution (Applied Biosystems, CA, USA). The SNP Genotyping Assay Mix consisted of specific forward (5'- CTG CGC TGG CAA TAC AGA TAA G - $3^{\prime}$ ) and reverse (5'- AAA TGC AAC CTA AGG AGG AGA GTT C-3') primers for amplifying and two TaqMan probes (each TaqMan probe contained a reporter dye at the $5^{\prime}$-position). The VIC reporter dye was attached at the $5^{\prime}$-position of the probe (ATA ATG TAG TCC CTG GCC T) to detect the T-allele. The 6-FAM reporter dye was attached at the $5^{\prime}$-position of the probe (ATA ATG TAG CCC CTG GC) to detect the $\mathrm{C}$-allele.

The amplification program involved an initiation step that began with the previous activation of AmpliTaq Gold ${ }^{\circledR}$ DNA polymerase (Applied Biosystems, CA, USA) for 2 minutes at $50^{\circ} \mathrm{C}$ and denaturation of double-stranded genomic DNA for 10 minutes at $95^{\circ} \mathrm{C}$. The PCR included 40 cycles, each of which consisted of annealing or complementary primer attachment to single-stranded DNA targets and elongation AmpliTaq Gold ${ }^{\circledast}$ DNA polymerase of the second DNA strand of $15 \mathrm{sec}$ at $92^{\circ} \mathrm{C}$ and $60 \mathrm{sec}$ at $60^{\circ} \mathrm{C}$. In the process of amplification, a simultaneous hybridizationfluorescence detection was performed on samples using fluorescent probes on a DNA analyzer according to the 
Assays-on-Demand protocols for SNP genotyping (No 4331183, Applied Biosystems, CA, USA) to the application Allelic Discrimination of the ABI PRISM 7000 SDS Software (Applied Biosystems, CA, USA).

Thus, three types of amplification products were determined:

1. determination of the fluorescent signal only from the $\mathrm{VIC}$ dye-homozygote genotype $\mathrm{T} / \mathrm{T}_{-13910}$,

2. fluorescent signals from the VIC dye and 6-FAM dyeheterozygote genotype $C / T_{-13910}$, and

3. fluorescent signal only from 6-FAM dye--homozygote genotype $\mathrm{C} / \mathrm{C}_{-13910}$.

To assess genotyping reproducibility, a random $10 \%$ selection of samples was re-genotyped with $100 \%$ concordance.

\section{Determination of the expression of Gal-9 of $m R N A$}

Study of the expression of Gal-9 mRNA from the buccal epithelium was conducted in a certified laboratory of the Department of General and Molecular Pathophysiology of the O.O. Bogomolets Institute of Physiology of the National Academy of Sciences of Ukraine using the RT-PCR method with reverse transcription according to TaqMan Gene Expression Assays protocol and included the following steps:

1. Isolation of Gal-9 mRNA from the primary material (buccal epithelium).

2. Preamplification (preparation of primers for mRNA). Mixed mRNA, 5X hexameric primer of arbitrary sequence SO142 Hexamer Random (Thermo Scientific, Carlsbad, CA, USA) and deionized water. Primary denaturation lasted 5 minutes at a temperature of $70^{\circ} \mathrm{C}$ in the thermocycler GeneAmp PCR System 2700 (Applied Biosystems, CA, USA).

3. Reverse transcription. Reverse transcription was performed using a hexamer primer using RevertAid Reverse Transcriptase (Thermo Scientific, CA, USA), selected $m R N A$, and reverse transcriptase. The resultant reverse transcription of single chain cloned DNA (CDNA) was used to quantify the expression of genes using PCR-RT using primers for the respective genes [TagMan Gene Expression Assay FAM (4448892) Assay ID Hs04190742_mH (LGALS9), and the TagMan $\beta$-Actin Control Kit Reagent (Applied Biosystems, CA, USA)]. Expression of genes has been standardized with respect to the expression of the $\beta$-actin gene as an endogenous control (one of the so-called Housekeeping genes).
4. The amplification was carried out using the 7500 Fast Real-Time PCR System (Applied Biosystems, CA, USA) thermocycler for 42 minutes. Data analysis was performed using 7500 Fast Real-Time PCR Software. The amplification program began with pre-activation of AmpliTaq Gold ${ }^{\circledR}$ DNA polymerase (Applied Biosystems, CA, USA) for 10 minutes at $95^{\circ} \mathrm{C}$ and included 45 cycles, each consisting of denaturation at $95^{\circ} \mathrm{C}(19 \mathrm{sec})$, primer attachment and elongation at $58^{\circ} \mathrm{C}(1 \mathrm{~min})$. To control the specificity, a dissociation stage was carried out, with a sequential increase in temperature from $58^{\circ} \mathrm{C}$ to $95^{\circ} \mathrm{C}$ with a registration of the drop in the fluorescence intensity of double-stranded DNA complexes with SYBR Green.

5. Data analysis was performed with 7500 Fast Real-Time PCR Software. The relative level of gene expression was determined using a generally accepted technique (expression level $=2^{\Delta \mathrm{Ct}}$, where $\mathrm{Ct}$ is the threshold amplification cycle).

Hydrogen breath test with lactose load (HBTLL)

The concentration of hydrogen in exhaled air was determined by the Gastro + Gastrolyser gas analyzer of the British company Bedfont ${ }^{\circ}$ Scientific Ltd in parts per million (ppm) with an accuracy of $\pm 1 \mathrm{ppm}$. Automatic data analysis was performed using GastroCHART software (Bedfont Scientific Ltd, Harrietsham, Maidstone, Kent, UK). Duration for HBTLL was 3 hours at intervals of 30 minutes. A test was considered positive when the level of hydrogen in exhaled air increased after 60 minutes by more than 20 ppm compared to the basal level and clinical symptoms of lactase intolerance (abdominal pain, flatulence, and diarrhea) appeared on a visual-analogue scale for the next eight hours of observations [18].

Depending on the $L C T$ genotyping data by RT-PCR, all children were divided into two groups: with the $C / C{ }_{-13910}$ genotype, which is associated with adult-type LD $(n=44$, I group) and with phenotypically genotypes $C / T$-13910, and $\mathrm{T} / \mathrm{T}$-13910, associated with heterozygous and homozygous lactase persistence ( $n=41$, II group). The first clinical group consisted of 27 boys (61.4\%) and 17 girls (38.6\%). The average age of the patients was $12.09 \pm 0.59$ years. The second clinical group was represented by 27 boys (65.85\%) and 14 girls (34.14\%). The average age of the examined was $12.19 \pm 0.12$ years $(p>0.05)$.

\section{Statistical analysis}

For statistical processing of research materials, the normality of the distribution of quantitative traits was checked according to the Shapiro-Wilk criterion. Data are 
expressed as mean \pm SEM. Intergroup comparisons of statistical characteristics were carried out taking into account the distribution law using parametric and nonparametric criteria. The reliability of differences in the mean values for unrelated samples was assessed by Student $(\mathrm{t})$ and Mann-Whitney $(\mathrm{U})$ criteria, for connected ones, by Student $(T)$ and Wilcoxon $(T)$, using Microsoft Excel (Office Home Business, USA) and STATISTICA 6.1 software (StatSoftInc, Tulsa, OK, USA). The critical value of the level of statistical significance in testing all null hypotheses was taken to be 0.05 (5\%).

RESULTS Genotype $\mathrm{C} / \mathrm{C}_{-13910}$ was registered in 44 (51.8\%), genotype $\mathrm{C} / \mathrm{T}{ }_{-13910}$ in 30 (35.3\%), and genotype $\mathrm{T} / \mathrm{T}$ in 11 (12.9\%) patients. Lactose maldigestion in children with genotype $\mathrm{C} / \mathrm{C}_{-13910}$ averaged $36.05 \pm 4.73 \mathrm{ppm}$, in children with genotypes $C / T-1391022.61 \pm 4.1 \mathrm{ppm}(p<0.05)$, and with genotype $T / T_{-13910}$ was absent $(p<0.05)$. The ratio of average values of hydrogen concentration in exhaled air under lactose loading in children with $\mathrm{T}_{\mathrm{T}} \mathrm{T}_{-13910}, \mathrm{C} / \mathrm{T}_{-13910 \text {, }}$ $\mathrm{C} / \mathrm{C}_{-13910}$ genotypes corresponds to $1: 17: 27$, respectively.

The average expression level of Gal-9 mRNA in children with genotype $C / C_{-13910}$, regardless of the level of lactose digestion, was $564.3 \pm 32.8$ RU $\triangle$ mRNA Gal-9/mRNA actin. At a relatively preserved level of lactose digestion in individuals with the $\mathrm{C} / \mathrm{C}_{-13910}$ genotype, overexpression of Gal-9 mRNA was 1086.73 \pm 52.6 RU $\triangle$ mRNA Gal-9/mRNA actin. The presence of clinically expressed lactose maldigestion in children with the $C / C_{-13910}$ genotype was associated with a pronounced reduction of Gal-9 mRNA expression, 42.47 \pm 13.3 RU $\Delta$ mRNA Gal-9/mRNA actin, $p$ $<0.001$. In children with the $\mathrm{C} / \mathrm{T}$ and $\mathrm{T} / \mathrm{T}_{-13910}$ genotypes, the expression level of Gal-9 mRNA was $61.04 \pm 15.3 \mathrm{RU}$ $\triangle$ mRNA Gal-9/mRNA actin, $p<0.01$.

The lowest mean level of expression of Gal-9 mRNA (42.47 \pm 13.4 RU $\triangle$ mRNA Gal-9/mRNA actin) was recorded in the subgroup of children with genotype $C / C_{-13910}$ and lactose maldigestion $(n=22)$. Whereas the largest mean level of expression of Gal-9 mRNA was recorded in the subgroup of children with the $\mathrm{C} / \mathrm{C}_{-13910}$ and without lactose maldigestion $(n=22) 1086.73 \pm 51.2$ relation units $\triangle m R N A$ Gal-9/mRNA actin, $p<0.01$.

DISCUSSION Studies in the Caucasian populations [7,1921] showed a high correlation between lactose digestion, intestinal lactase levels, and genetic tests in individuals with different SNP MCM6 genotypes.

Previous studies have shown that administration of $\beta$ lactose causes inflammation similar to the effects obtained in knocked out mice of the Lgals9 gene [1,22]. With an excessive concentration of lactose, the highest proliferative activity of mature cytotoxic $\mathrm{CD} 8^{+} \mathrm{T}$ lymphocytes observed in the acute phase of the inflammatory process [23]. Lactose, binding to Gal-9, prevents the activation of Tim-3 and plays a decisive role in the trigger of $\mathrm{Th}_{1}$ and $\mathrm{Th}_{17}$-associated reactions. Under physiological conditions, $\mathrm{T}_{\text {reg }}\left(\mathrm{CD} 4^{+} \mathrm{CD} 25^{+} \mathrm{CD} 127^{-}\right)$cells in vitro inhibit IFN- $\gamma$ secretion $(3.9-8.8 \mathrm{ng} / \mathrm{ml}, \mathrm{n}=20 ; p=0.003)$ by $\mathrm{Th}_{1}$ and IL-17 cells $(0.64-0.83 \mathrm{ng} / \mathrm{ml}, \mathrm{n}=15 ; p=0.04)$ for $\mathrm{Th}_{17}$ cells. In the presence of lactose, $\mathrm{T}_{\text {reg }}$ cells lose their ability to inhibit the secretion of IFN- $\gamma$ and IL-17 (16.4 vs. $3.99 \mathrm{ng} / \mathrm{ml}, \mathrm{n}=20, p<0.0001$ and 0.74 vs. $0.64 \mathrm{ng} / \mathrm{ml}, \mathrm{n}=15$, $p=0.005$, respectively) [10]. Thus, there is an increase in cellular pro-inflammatory processes, as well as the induction of autoimmune diseases and delayed hypersensitivity reactions that support chronic inflammation [24] and tumor processes [25,26].

However, our study first demonstrated the relationship between the level of Gal-9 expression and the genetically determined risk of insulin resistance due to the presence of an adult-type lactase deficiency.

In children with the $\mathrm{C} / \mathrm{C}_{-13910}$ genotype, the level of Gal-9 mRNA expression depends on the level of lactose digestion. Decreased expression of Gal-9 mRNA due to mating with impaired lactase synthesis or the effect of lactose excess may underlie the pro-inflammatory response associated with insufficient activity of the inhibitory signal associated with Tim-3. In our opinion, a study of the expression of Gal-9 mRNA in children with the $\mathrm{C} / \mathrm{C}_{-13910}$ genotype can serve as a marker for early diagnosis of the tendency of an unfavorable course of lactase deficiency (obesity, insulin resistance, type 2 diabetes mellitus).

CONCLUSIONS In children with the $\mathrm{C} / \mathrm{C}_{-13910}$ genotype, the expression level of Gal-9 mRNA depends on lactose maldigestion, which requires replacement therapy or a low-lactose diet. In our opinion, studies on the expression of Gal-9 mRNA in obese children with lactose maldigestion contribute to a more in-depth understanding of the persistence of compensatory mechanisms that ensure lactose hydrolysis than HBTLL.

\section{REFERENCES}

[1] Enattah NS, Sahi T, Savilahti E, Terwilliger JD, Peltonen $L$, Järvelä I. Identification of a variant associated with 
adult type hypolactasia. Nat Genet. 2002 Feb; 30(2):233-7.

[2] Hassan MS, Shaalan AA, Dessouky MI, et al. A review study: Computational techniques for expecting the impact of non-synonymous single nucleotide variants in human diseases. Gene. 2019 Jan 5; 680: 20-33. doi: 10.1016/j.gene.2018.09.028.

[3] Torniainen S, Freddara R, Routi T, et al. Four novel mutations in the lactase gene (LCT) underlying congenital lactase deficiency (CLD). BMC Gastroenterol. 2009 Jan 22;9:8. doi: 10.1186/1471230X-9-8.

[4] Liebert A, López $S$, Jones BL, et al. World-wide distributions of lactase persistence alleles and the complex effects of recombination and selection. Hum Genet. 2017 Nov; 136(11-12):1445-1453. doi: 10.1007/s00439-017-1847-y.

[5] Kuokkanen M, Enattah NS, Oksanen A, Savilahti E, Orpana A, Järvelä I. Transcriptional regulation of the lactase-phlorizin hydrolase gene by polymorphisms associated with adult-type hypolactasia. Gut. 2003 May; 52(5):647-52.

[6] Abaturov AE. [Peculiarities of metabolic syndrome in children]. Children's doctor. 2011; 4 (11): 54-61. [Article in Russian].

[7] Gorman JV. Regulation of T cell responses by the receptor molecule Tim-3. Immunol Res. 2014; 59 (13): 6-65. doi:10.1007/s12026-014-8524-1.

[8] Tureci O, Schmitt H, Fadle N. et al. Molecular definition of a novel human galectin which is immunogenic in patients with Hodgkin's disease. J Biol Chem. 1997; 272: 6416-6422. doi:10.1074/jbc.272.10.6416.

[9] Jacobs J, Smits E, Lardon F, Pauwels P. Deschoolmeester Immune Checkpoint Modulation in Colorectal Cancer: What's New and What to Expect. J Immunol Res. 2015:158038. doi: 10.1155/2015/158038.

[10] Paasela M, Kolho K-L, Vaarala O et al. Lactose inhibits regulatory T-cell-mediated suppression of effector Tcell interferon- $\gamma$ and IL-17 production. Br. J. Nutr. 2014; 112(11): 1819-1825. doi:10.1017/S0007114514001998.

[11] Sakuishi K, Jayaraman P, Behar SM. Emerging Tim-3 functions in antimicrobial and tumor immunity.

Trends Immunol. 2011;32 (8): 345-9. doi: 10.1016/j.it.2011.05.003.

[12] Brinchmann MF, Patel DM, Iversen MH. The Role of Galectins as Modulators of Metabolism and Inflammation. Mediators Inflamm. 2018 May 21; 2018:9186940. doi: $10.1155 / 2018 / 9186940$
[13] Abaturov AE, Stepanova YuYu, Nikulina AA. [Persistence and deficiency of lactase]. Pediatrics. Eastern Europe. 2015; 4 (12): 87-97. [Article in Russian].

[14] Sun J, Huang Q, Li S et al. miR-330-5p/Tim-3 axis regulates macrophage $\mathrm{M} 2$ polarization and insulin resistance in diabetes mice. Mol Immunol. $2018 \mathrm{Mar}$; 95:107-113. doi: 10.1016/j.molimm.2018.02.006.

[15] Yan WJ, Sun P, Wei DD et al. T cell immunoglobulin and mucin domain-containing molecule 3 on CD14+ monocytes serves as a novel biological marker for diabetes duration in type 2 diabetes mellitus. J Diabetes Investig. 2016 Nov; 7(6):867-873. doi: 10.1111/jdi.12523.

[16] Albuquerque D, Nobrega C, Manco L. The lactase persistence $-13910 \mathrm{C}>\mathrm{T}$ polymorphism shows indication of association with abdominal obesity among Portuguese children. Acta Pædiatrica 2013; 102: 153-157. doi:10.1111/apa.12134.

[17] Ridefelt P, Hakansson LD. Lactose intolerance: lactose tolerance test versus genotyping. Scand J Gastroenterol. 2005 Jul; 40(7):822-6. doi: 10.1080/00365520510015764.

[18] Mottes M, Belpinati F, Milani M et al. Genetic testing for adult-type hypolactasia in Italian families. Clin Chem Lab Med. 2008; 46(7):980-4. doi: 10.1515/CCLM.2008.189.

[19] Abaturov A, Stepanov Y, Nikulina A. Treatment of lactase deficiency in children's obesity with genotype C/C 13910 of lactase gene. Wiad Lek. 2019;72(1):1721. PMID: 30796855.

[20] Houben E, De Preter V, Billen J et al. Additional Value of $\mathrm{CH}_{4}$ Measurement in a Combined (13) $\mathrm{C} / \mathrm{H}_{2}$ Lactose Malabsorption Breath Test: A Retrospective Analysis. Nutrients. 2015 Sep 7; 7(9): 7469-85. doi: 10.3390/nu7095348., 53, 210.

[21] Mądry E, Lisowska A, Kwiecień J et al. Adult-type hypolactasia and lactose malabsorption in Poland. Acta Biochim Pol. 2010; 57(4): 585-8. PMID: 21152447

[22] Wu Ch, Thalhamer T, Franca RF, et al. The interaction of galectin-9-CD44 increases the stability and function of adaptive regulatory T cells. Immunity. 2014 Aug 21; 41 (2): 270-282. doi: 10.1016/j.immuni.2014.06.01 .01

[23] Savaiano DA. Lactose intolerance: Perceptions, scientific realities and management. Journal of Nutrition \& Intermediary Metabolism. 2017; 8: 63-64. doi. org/10.1016/j. jnim.2017.04.009. 
[24] Vonk MM, Diks MAP, Wagenaar L, et al. Improved Efficacy of Oral Immunotherapy Using Non-Digestible Oligosaccharides in a Murine Cow's Milk Allergy Model: A Potential Role for Foxp3+ Regulatory T Cells. Front Immunol. 2017; 8: 1230 . doi: 10.3389/fimmu.2017.01230.

[25] Liu JF, Wu L, Yang LL, et al. Blockade of TIM3 relieves immunosuppression through reducing regulatory $T$ cells in head and neck cancer. J Exp Clin Cancer Res. 2018 Mar 5;37(1):44. doi: 10.1186/s13046-018-07137.

[26] Wang Y, Zhao E, Zhang Z, et al. Association between Tim-3 and Gal-9 expression and gastric cancer prognosis. Oncol Rep. 2018 Oct;40(4):2115-2126. doi: 10.3892/or.2018.6627. 